\title{
EVENTS \\ AND CONFERENCES
}

Magdalena Marcinkowska*

\section{"Aim - the 1995 UNIDROIT Convention" Current Legal Instruments against Heist and the Illegal Exportation of Cultural Goods}

Warsaw, 17 December 2014

The illicit trade in artefacts, the grey shades of the art market, and the legal instruments used to fight the illicit trafficking in antiquities were the main issues discussed at a conference held on the $17^{\text {th }}$ of December 2014 at the Ministry of Foreign Affairs of the Republic of Poland, in Warsaw. The conference, entitled "Current Legal Instruments against Heist and the Illegal Exportation of Cultural Goods", was organised in connection with the upcoming anniversary of the 1995 UNIDROIT Convention on Stolen or Illegally Exported Cultural Objects (1995 UNIDROIT Convention) - one of the main international legal instruments prohibiting unlawful transactions in works of art. At the same time, a major reason behind organization of the conference was to analyse the legal status of imports and exports of cultural goods in Poland, as well as the recent legislative procedures undertaken by the Ministry of Foreign Affairs aimed at Poland's accession to the treaty.

\footnotetext{
* Magdalena Marcinkowska, Gdańsk, Poland, recently completed a PhD in Law at the University of Gdańsk. Her research focuses on legal mechanisms in managing cultural heritage on international and domestic (national) levels, and their mutual interaction and cross-fertilisation.
} 


\section{EVENTS AND CONFERENCES}

Magdalena Marcinkowska

Guests and experts in art law from all over the country were welcomed by Professor Artur Nowak-Far, Undersecretary of State in the Ministry of Foreign Affairs in years 2013-2015, who opened the conference and pointed out the functions and mechanisms of international regulations on illegally dislocated objects, using the 1995 UNIDROIT Convention as the main example. He also confirmed that it is crucial for Polish cultural heritage protection policy that Poland ratify this treaty in the near future and begins to implement its provisions.

In the first part of the conference the speakers referred to the problem of illicit trafficking of antiquities and their presence on the art market, which is one of the major problems when it comes to protecting cultural heritage. Dr Wojciech Szafrański from the Adam Mickiewicz University in Poznań devoted his presentation to pointing out the myths and pathologies in today's art trade. One of the main perils is the myth of traditional classification of the art market into black and white (legal and illegal), while in reality it also contains many shades of grey. Within these shades all the pathologies come into play, for instance corruption, price manipulation, and even the legalisation of stolen and excavated objects. Dr Szafrański concluded by pointing out that these pathologies are becoming in practice a troublesome bone of contention between an owner (seller) and a buyer in good faith.

The next speaker, Dr Alicja Jagielska-Burduk from the University of Kazimierz Wielki in Bydgoszcz, discussed the issue of the purchase of a cultural object from an non-owner, demonstrating that that nowadays there is no proper balance between the protection of a purchaser and an owner of cultural goods, just as there is no proper correspondence between the protection of cultural heritage and art market safety. The latter issue mainly focuses on the buyer, not on the owners' rights. This is exemplified in a good faith acquisition, which gives protection to a buyer who purchases a cultural object from a non-owner. She pointed out that the proposed amendment to Polish law on found property may influence the situation concerning the proper balance in the art market, by providing cultural objects with a special legal regime and entering them on a national register of lost goods.

European solutions for returning cultural objects to their rightful owner were presented by Professor Piotr Stec from the University of Opole. The subject of his presentation was the twenty years of functioning of the Council Directive 93/7/EEC of 15 March 1993 on the return of cultural objects unlawfully removed from the territory of a Member State. Professor Stec criticised the Directive, pointing out its ineffectiveness, which was related to the narrow definition of the term "cultural good", weak administrative instruments of cooperation, as well as the risks of court proceedings concerning the payment of compensation to the possessor of a cultural good unlawfully removed, or execution proceedings concerning the return of a cultural object. As a remedy to existing status quo, Professor Stec pointed to the necessity for proper implementation of the new Directive 2014/60/EU of the European Parliament and of the Council of 15 May 2014 on the return of cultural objects unlawfully removed from the territory of a Member State and amending 
Regulation (EU) No. 1024/2012 (Directive 2014/60/EU), which would potentially create a solid system for the return of cultural goods in Europe.

The second part of the conference was opened by Professor Katarzyna Zalasińska from University of Warsaw, who presented the main obligations of the first legal instrument concerning this matter at the international level - the UNESCO Convention on the Means of Prohibiting and Preventing the Illicit Import, Export and Transfer of Ownership of Cultural Property (1970 UNESCO Convention). Forty years of its existence in the international system of cultural heritage protection shows that, despite some revealed deficiencies, the UNESCO Convention contains one main feature which is still of great importance: it gives States Parties an international cooperation framework within which to combat the illicit trade of cultural objects. In discussing the implementation of its provisions in the Polish legal system, Professor Zalasińska stressed that Poland has still not implemented the export regulations required by Convention, nor are prevention activities provided by, for instance, education, and there is a great need for art market monitoring.

The conference closed with a speech by Professor Wojciech Kowalski from the University of Silesia in Katowice, who presented the arguments underlying the legal solutions of the 1995 UNIDROIT Convention. The first concerned its core principle, which obligates a new possessor to return a stolen cultural object. The second set of arguments concentrated on the limitations periods for bringing restitution claims into court; which are three years' from the time the claimant knew the location of the cultural object and the identity of its possessor, and not more than 50 years from the time of the theft, or where relevant from the date of the export or from the date on which the object should have been returned. The third argument was devoted to the provisions for compensation to a buyer in good faith. In conclusion it was stressed that the main goal of the analysed Convention was to create an international instrument to help prevent the growing pathologies in the international art market.

All the above-mentioned speeches were published in the "Santander Art and Culture Law Review" in its first issue, in 2015. 